\title{
Hydraulic Conductivity and Landfill Construction
}

\author{
Witold Stępniewski1, Marcin K. Widomski ${ }^{1}$ and Rainer Horn ${ }^{2}$ \\ ${ }^{1}$ Lublin University of Technology, Faculty of Environmental Engineering, \\ Dept of Land Surface Protection, \\ ${ }^{2}$ Christian Albrechts University, Institute for Plant Nutrition and Soil Science, \\ 1 Poland \\ ${ }^{2}$ Germany
}

\section{Introduction}

Landfills are important engineered constructions spread all over the world. Their number is calculated in thousands as the production of wastes in Europe only, reaches each year 3000 million tones of which $14 \%$ (about $415 \mathrm{~kg}$ per capita) is municipal waste (EEA, 2004). Of this in 1999 about $57 \%$ was landfilled, $16 \%$ was incinerated, $20 \%$ recycled and composted and $7 \%$ was treated in other way. There are numerous types of landfills from simple dumping sites to rather sophisticated constructions constituting real bioreactors. Due to uncountable biochemical reactions occurring within the waste body, landfills produce biogas and leachates which threaten the pollution of air, water and soil. The environmental impact of landfills depends, to a high extent, on a bottom liner and top capping isolating the landfill from the surrounding. The quality of this isolation is determined by the water permeability as, in fact, no constructions are completely impermeable.

There are two essential types of liners i.e. mineral clay liners and synthetic liners of different geomembranes (or combination of both). As durability of synthetic liners is limited in time the mineral clay liners, which can persist thousands of years, if managed in a sophisticated way as it was proved by the countless layered natural soils worldwide, are preferred as a long term impermeable and rigid system. It is necessary to emphasize that landfill should preferably have a bottom liner and top capping. The function of bottom liner is to prevent the deeper soil layers and the groundwater from contamination with soluble substrates and irreversible pollution of the future drinking water reservoirs. The function of the top capping is to avoid infiltration of the precipitation water (from rain and from snow melting) and migration of methane and odors from the biogas to the atmosphere. However, the top capping system also has to guarantee optimal (or at least satisfactory) conditions for plant growth while the deep rooting of plants must be prevented. Thus, these conflicting requirements can be only fulfilled by special mineral soil systems which, if they are adjust, will preserve their properties for ever.

\section{Materials appropriate for mineral liner construction}

The EU Landfill Directive (1999/31/EC) distinguishes three types of landfills i.e. landfills for hazardous waste, landfills for non hazardous waste, and landfills for inert waste. This directive, among others, says that the landfill must be situated and designed in a way ensuring the prevention of pollution of atmosphere, groundwater, surface water and soil. It 
can be achieved by combination of bottom liner and geological barrier during operation phase, and by combination of geological barrier and top liner during the aftercare phase.

The directive determines that landfill base and sides should consist of mineral layer with the following requirements:

- landfill for hazardous waste - the layer should be characterized by the hydraulic permeability $\mathrm{k}$ equal or lower than $10^{-9} \mathrm{~m} \cdot \mathrm{s}^{-1}$ and thickness equal at least $5 \mathrm{~m}$,

- landfill for non hazardous waste - the same permeability and thickness equal or higher than $1 \mathrm{~m}$,

- $\quad$ landfill for inert waste -hydraulic permeability of $10^{-7} \mathrm{~m} \cdot \mathrm{s}^{-1}$ or less and thickness of at least $1 \mathrm{~m}$.

In case of lack of a natural geological barrier it can be prepared artificially. The minimum thickness of artificially established barrier is $0.5 \mathrm{~m}$. For non hazardous and hazardous landfill categories an artificial sealing liner and a drainage layer $(\geq 0.5 \mathrm{~m})$ is required.

Often local soils can be used for construction of landfill bottom liner, after application of external loads leading to their compaction. Usually recommended soil properties to achieve hydraulic permeabilities of order $10^{-9} \mathrm{~m} \cdot \mathrm{s}^{-1}$ by compaction are: percentage of fines $(<0.075 \mathrm{~mm})$ $\geq 30 \%$, plasticity index between 20 and 30 and percentage of gravel ( 5 to $50 \mathrm{~mm}$ ) $\leq 20 \%$ (Roehl et al., 2009). The ranges of grain size - distributions providing hydraulic conductivities $\mathrm{k} \leq 10^{-7}$ $\mathrm{m} \mathrm{s}^{-1}$ appropriate for landfill liner constructions are presented in Fig. 1.

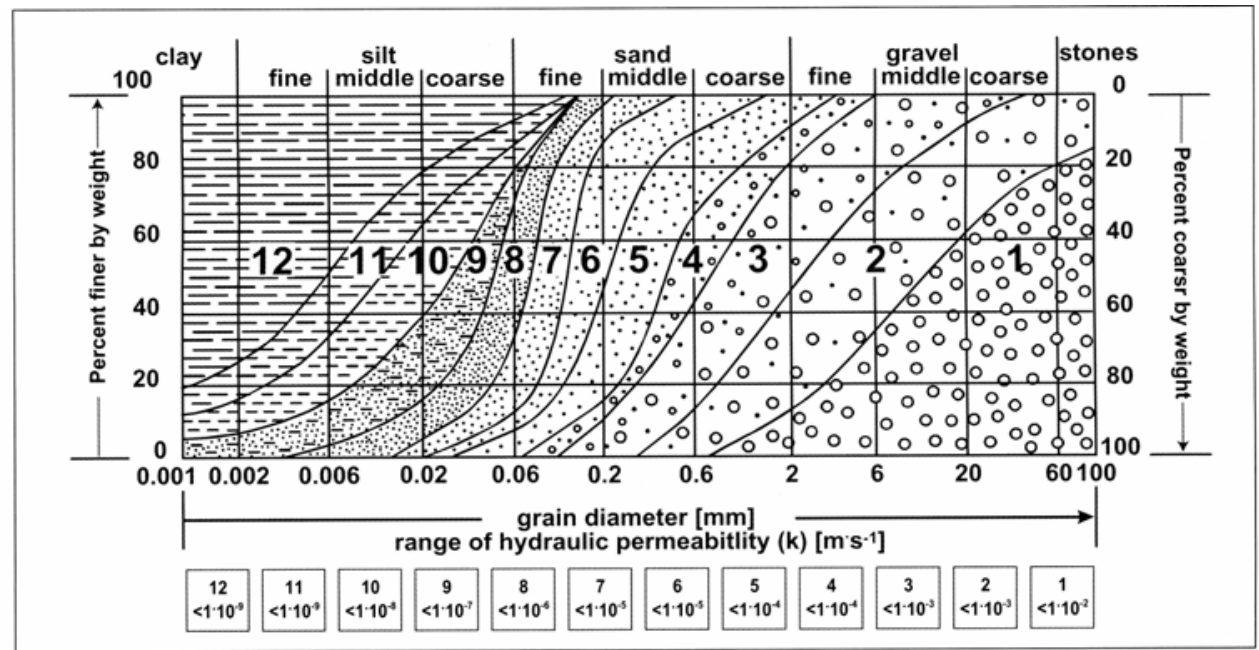

Fig. 1. Ranges of hydraulic permeability (expressed as $\mathrm{k}$ coefficient in $\mathrm{m} \cdot \mathrm{s}^{-1}$ ) as related to grain-size distribution areas. The range of $\mathrm{k} \leq 10^{-7} \mathrm{~m} \cdot \mathrm{s}^{-1}$ is considered as an important barrier feature for mineral sealing in most of national regulations. Grain size distribution areas 10, 11 and 12 refer to this range. After Alamgir et al. (2005).

\section{Factors affecting hydraulic permeability}

\subsection{Theoretical background}

Laminar flow rate of a liquid through a cylindrical capillary, according to Hagen-Poiseuille equation is proportional to the $4^{\text {th }}$ power of the capillary diameter. The other factors are the gradient of pressure constituting the external driving force of the flow and the dynamic 
viscosity being the property of the liquid itself. In case of porous materials (such as eg. soil) characterized by a very complicated pore structure the laminar flow rate, as described by equation of Darcy (1856) is proportional to the pressure gradient and hydraulic permeability $\mathrm{k}$ characterizing the properties of the material in which the flow takes place.

Hydraulic conductivity $\mathrm{k}$ is related to soil and permeating fluid according to Kozeny Carman equation (Mitchel \& Soga, 2005):

$$
k=\frac{\rho g}{\mu} \frac{1}{K_{n} T^{2} S_{0}^{2}}\left(\frac{e^{3}}{1+e}\right) S^{3}
$$

Where the particular symbols have the following meaning:

$\mathrm{k}$ - hydraulic conductivity, $\mathrm{g}$ - acceleration of gravity, $\rho$ - fluid mass density, $\mu$ - fluid viscosity, $\mathrm{T}$ - tortuosity, $\mathrm{K}_{\mathrm{n}}$ - pore shape factor, $\mathrm{S}_{0}$ - wetted surface area per unit volume of particles, e - void ratio, $\mathrm{S}$ - degree of saturation.

Thus, any factors affecting the above properties should result in altering the water permeability of porous material applied to municipal waste landfill bottom liner.

It was confirmed experimentally that soil hydraulic conductivity depends, among others, on its particle size distribution and specific surface area as well as on void ratio, swelling and ion exchange capabilities (Alamgir et al., 2005; Baumann, 1999; Benson \& Trast, 1995; Egloffstein, 2001; Foged \& Baumann 1999; Mitchell \& Jaber 1990; Vukovic \& Soro, 1992). Hydraulic conductivity usually decreases with the increase of the content of fine particles (Alamgir et al., 2005; Sivapullaiah et al., 2000), as shown in Fig. 1.

\subsection{Compaction effects on hydraulic conductivity of soil materials}

The key question for solid municipal wastes landfill constructors and operators is how to reduce the negative effects of the waste body like landslides, leachate infiltration to ground water and soil, odors, rain and wind erosion on the surrounding environment. An appropriate isolation of waste body can be achieved by the construction of bottom and top liners limiting the leachates outflow and infiltration of water (e.g. Bagchi, 2004; Horn \& Stępniewski, 2004; Tatsi \& Zouboulis 2002; Wysocka et al., 2007) while allowing at the same time the gas emission and oxygen inflow in the top capping. According to literature reports and engineering practice two different approaches of liner construction may be observed: application of polymer membranes and usage of frequently local mineral materials containing significant amounts of clay (Bagchi, 2004). Both approaches have their benefits and limits but in some cases, especially in developing countries application of mineral clay liners, despite risk of cracking, sometimes supported by simple membranes is welcome by the local authorities (e.g. Ahmed, 2008; Gunarathna et al., 2007;). Such attempts were noted not only in e.g. Asian less developed countries but also in Europe.

Water permeability of natural soils is often higher than the required values described by national and international standards for bottom liner construction (in most countries, as it was mentioned earlier the minimum required saturated conductivity for bottom liner should be no more than $1 \cdot 10^{-9} \mathrm{~m} \cdot \mathrm{s}^{-1}$ ) and unsuitable even for top capping constructions. Consequently mechanical compaction approaches can be used to decrease the hydraulic conductivity. However, such mechanical compaction caused by external loads generating static and dynamic forces leads to increased bulk density, decreased porosity as well as shifts in pore shapes and size distributions but reduces the strength of the system because of an anthropogenically created positive pore water pressure due to dynamic kneading. (e.g. Flowers \& Lal, 1998; Radford at al., 2000; Horn, 2004; Yavuzcan et al., 2005; Zhang et al., 2006). 
The influence of compaction process on hydraulic properties of soil can be easily explained by the Hagen - Poiseuille law and was proved amongst others by Kooistra and Tovey (1994) who found out that a voids reduction in size and shape caused by passing wheeling machines resulted in smaller macroporosity (pore diameter $>100 \mu \mathrm{m}$ ) by approx. $3 \%$.

Irrespective of cracking risks - which can be prevented by compaction at the water content lower than the water content at Proctor density - such compacted liners made of local soils or other materials (by-products, bentonite-soil mixtures etc.) are commonly applied in construction of municipal solid waste landfills. According to numerous reports, they appear successful in limiting infiltration of leachates to soil and groundwater environment as well as reducing infiltration of surface water into waste body (e.g. Ahn \& Jo 2009; Bagchi, 2004; Gunarathna, 2007; Horn \& Stepniewski, 2004; Islam et al., 2008; Wysocka et al., 2007).

Figure 2 presents the reported effects of compaction on hydraulic conductivity of selected different porous materials (local soils, industrial by-products and bentonite mixtures) applied in construction of European or Asian landfills bottom and top liners. The degree of compaction is reflected by soils bulk density changed after stress application.

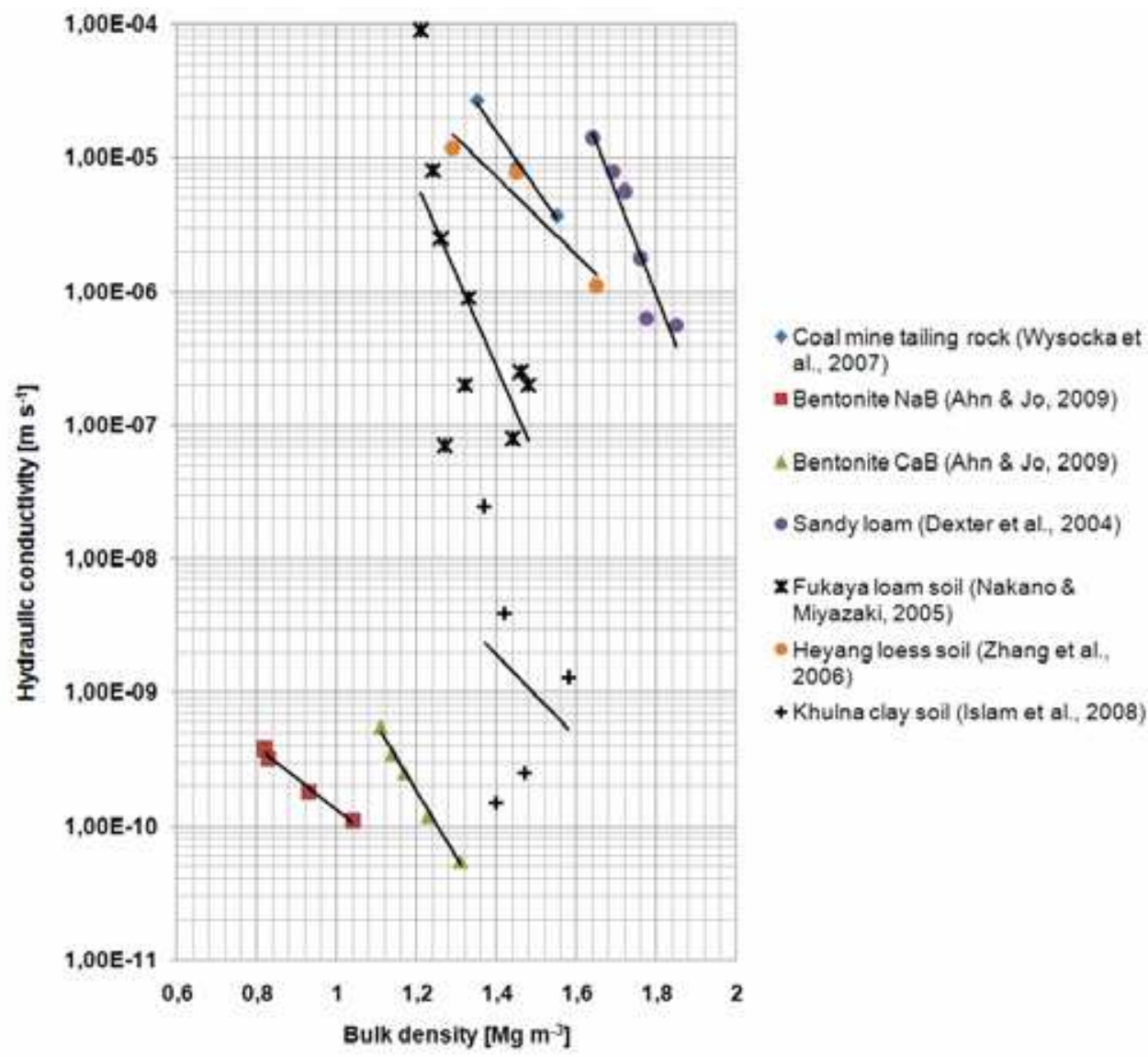

Fig. 2. Effect of bulk density on hydraulic conductivity of various porous materials (compiled from different sources) 
Presented results of literature studies show that several local soils and other porous materials after compaction fulfill the requirements of solid waste landfills' liners construction. Reports state that loess, sandy loam and loam soils as well as coal mining tailing rock are applicable to construction of landfills' top liners presenting saturated water conductivity reaching the value of $10^{-6}-10^{-7} \mathrm{~m} \cdot \mathrm{s}^{-1}$. Observed value of tested porous materials' hydraulic conductivity significantly may reduce the infiltration of surface water to waste body through landfill top capping.

The other compacted materials presented in Fig. 2 such as clay soil and bentonite mixtures, may be useful in construction of landfill bottom liners - the application of compaction process resulted in reduction of saturated hydraulic conductivity below $10^{-9} \mathrm{~m} \cdot \mathrm{s}^{-1}$, even in case of bentonite below $10^{-10} \mathrm{~m} \cdot \mathrm{s}^{-1}$.

Changes in pore size and continuity, however, alter the hydraulic conductivity and water retention characteristics, which initially may result in reduced infiltration abilities and limited storage capacity but - on the long run - because of swelling and shrinkage which coincides with a non rigid pore system, we even determine higher values of the hydraulic conductivity. Thus, the impacts of soils compaction depend, among others, on soil type, soil moisture during compacting, intensity and kind of loading as well as frequency. Junge et al. (2000) proved that in the course of soil compaction and re-drying these weak substrates crack and result in the formation of new macropores with a very high hydraulic conductivity. The results presented by Islam et al. (2008) on compaction of clay soil applied to construction of bottom liner of an experimental municipal solid waste landfill in Khulna, Bangladesh showed that molding water content during the compaction process affects the value of hydraulic conductivity of compacted soils irrespective of the obtained bulk density value ( Fig. 3).
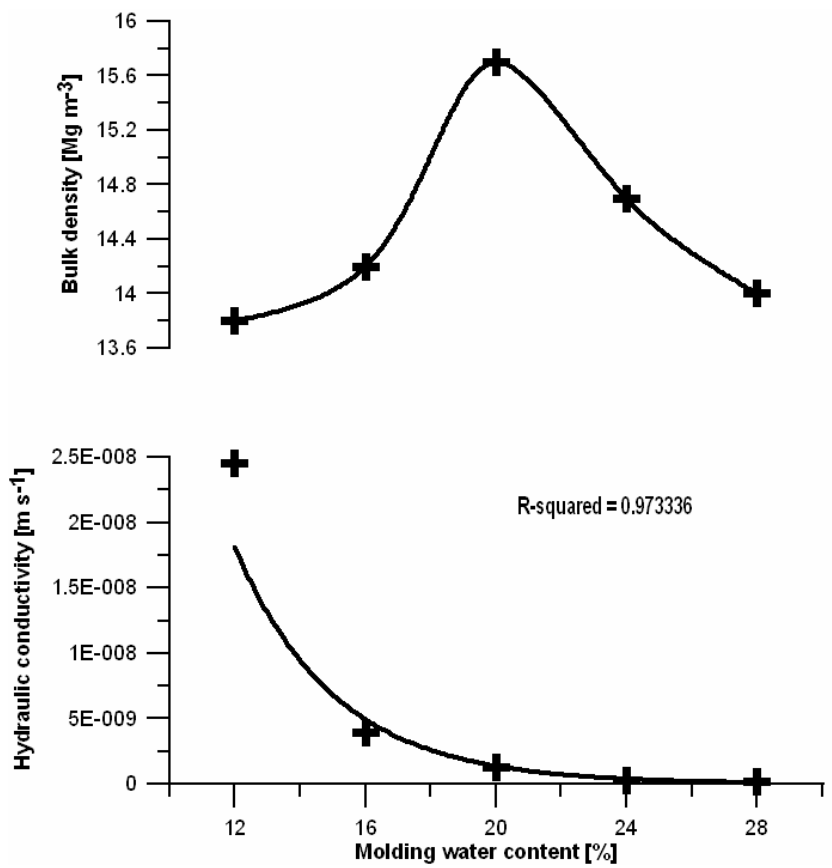

Fig. 3. Proctor curve and hydraulic conductivity of compacted clay soil, versus molding water content. Based on Islam et al. (2008). 
As it can be seen, the same bulk density can be achieved at two different levels of molding water content during the process of compaction both on the left and right side of Proctor's curve. Increase of molding water content resulted in a decrease of hydraulic conductivity down to $2.5 \cdot 10^{-10} \mathrm{~m} \cdot \mathrm{s}^{-1}$ at molding water content of $28 \%$. Nonetheless this situation is not reflected in changes of saturated hydraulic conductivity of the tested soil and only focus on the short time effect while the shrinkage induced crack formation thereafter enhances the hydraulic conductivity by many orders of magnitude (Junge et al., 1997).

\subsection{Influence of leachates on water permeability}

Municipal landfill leachates, generated during infiltration of surface (rain or melted snow) water through the waste body, are commonly considered as one of the most dangerous types of wastewater, significantly influencing environmental conditions as containing high concentrations of ammonium, salts, organic matter, etc. (Di Iaconi et al., 2010). The volume of leachates and their composition depend on the amount of water infiltrating the waste body, and on chemical reactions occurring between the solid and liquid phases dissolution, ion exchange and biochemical processes (Francisca \& Glatstein, 2010). The reported full composition of leachates of different municipal solid waste landfills all over the world were presented by e.g. Ehrig (1989); Fatta et al. (1998), Kjeldsen \& Christoffersen (2001), Kylefors (2003), Kulikowska \& Klimiuk (2008); Tatsi \& Zouboulis (2002) and Ziyang et al. (2009).

Migration of leachates generated inside the waste body of municipal landfill to soil and groundwater is prevented by bottom liners of different construction based on porous materials of low permeability. As it was mentioned, bottom liners usually have multilayer layout and consist of natural or compacted clay or mixtures of clayey soils, granular filters and geosyntetics (e.g.: Francisca \& Glatstein, 2010; Ozcoban et al., 2006; Petrov \& Rove 1997; Touse- Foltz et al., 2006).

Particle size, specific surface area, void ratio and fluid properties as well as soil fabric, compaction energy and thixotropy are the main factors limiting the water and contaminants movement in compacted porous materials of landfill liners (Benson \& Trast 1995; Vukovic \& Soro, 1992). According to reported numerous studies (e.g. Mitchell \& Jaber, 1990, Sivapullaiah 2000; Schmitz 2006) evaluating soil and liquid properties controlling the saturated hydraulic conductivity in liners, hydraulic conductivity decreases along with increased content of fine particles. The increased mechanical stress observed in compacted soils results in reduction of electrical forces effect on soil behavior but the soil fabric is affected by the chemical properties of the flowing liquid (Mitchell \& Soga, 2005). The other important factor influencing soil behavior is its retention capacity depending on adsorption mechanisms delaying the transport of contaminants through the soil (Francisca \& Glatstein, 2010); ions present in permeating liquid are absorbed by mineral phase surface, in the rate and amount controlled by surface charge density, ion concentration and valence, and $\mathrm{pH}$. So, according to Schmitz (2006) landfill leachate containing high ionic concentration should increase the hydraulic conductivity as increased ionic concentration should decrease the double-layer thickness. But, as it was reported (e.g. Francisca \& Glatstein, 2010; Mitchell \& Soga, 2005) this mechanism has sometimes a negligible effect on the experiment field test since it is relevant only in case of high porosity or freshly compacted soils.

Another factor influencing changes of hydraulic conditions of liner porous material treated with leachates is bioactivity causing pore clogging (e. g. Brovelli et al., 2009). Nutrients load present in leachates is responsible for increased formation and development of bacteria and 
yeast colonies resulting in partial or permanent soil pore blocking (Francisca \& Glatstein, 2010; Rebata-Landa \& Santamarina, 2006). Decrease of porous media hydraulic conductivity may be in this case related to the presence of biofilm covering surface of mineral particles, thus significantly reducing sizes of micropores and increasing the resistance of fluid flow.

Research concerning effects of leachate on hydraulic conductivity of natural clay was conducted by Ozcoban et al., (2006). Natural clay soils applied as liner in municipal solid waste landfill in Kemerburgaz, Turkey, were tested. Soil samples containing kaolinite were permeated with distilled water and leachate in a vertical reactor - constant head permeameter (each test lasted 3-4 weeks). Tests conducted by Ozcoban et al., (2006) confirmed that clay soils, under laboratory conditions show a very little increase of hydraulic conductivity after being permeated with leachate: $9.848 \cdot 10^{-10} \mathrm{~m} \cdot \mathrm{s}^{-1}$ for water vs. $10.8 \cdot 10^{-10} \mathrm{~m} \cdot \mathrm{s}^{-1}$ for leachate.

The hydraulic and compaction characteristics of leachate-contaminated lateric Indian soil were presented by Nayak et al. (2007). The soil was sampled at local open waste dump where municipal solid wastes were deposited without shredding and segregation. Four different levels of leachate concentration were tested: $0 \%, 5 \%, 10 \%$ and $20 \%$. The increase of hydraulic conductivity of soil due to leachate addition was observed (see Table 1).

\begin{tabular}{|c|c|c|}
\hline Leachate content & $\begin{array}{c}\mathrm{k} \\
10^{-7}\left[\mathrm{~m} \cdot \mathrm{s}^{-1}\right]\end{array}$ & $\begin{array}{c}\text { Increase } \\
\%\end{array}$ \\
\hline $0 \%$ & 3.07 & - \\
\hline $5 \%$ & 3.698 & 20.46 \\
\hline $10 \%$ & 4.542 & 22.82 \\
\hline $20 \%$ & 5.792 & 27.52 \\
\hline
\end{tabular}

Table 1. Effect of leachate concentration on hydraulic permeability of lateric soil (Nayak et al., 2007)

These observations fully support the earlier mentioned thesis of Mitchell \& Soga (2005) or Schmitz (2006) and prove increase of hydraulic conductivity of leachate treated soils.

Not numerous investigations were conducted to define the influence of leachates presence on hydraulic conductivity of porous materials applied to bottom liners of municipal solid waste landfill. Studies of Francisca \& Glatstein (2010) focused on long term hydraulic conductivity of compacted silt soils of Chaco-Pampean plain, Argentina, also with 5\% and $10 \%$ bentonite addition. Permeability tests were conducted for distilled water and filtered landfill leachate. The compaction liquid content was at the constant level of $20 \%$. Hydraulic conductivity was measured weekly during the period of 15 months by the standard falling head procedure according to ASTM D5856 (Francisca \& Glatstein, 2010). Observations showed a decrease of pore volume of flow after 15 months treating soil samples with leachate - Table 2.

\begin{tabular}{|l|c|c|}
\hline & \multicolumn{2}{|c|}{ Pore volume of flow } \\
\hline \multicolumn{1}{|c|}{ Sample } & Distilled water & Leachate \\
\hline $0 \%$ of bentonite & 3.6 & 1.37 \\
\hline $5 \%$ of bentonite & 2.3 & 1.51 \\
\hline $10 \%$ of bentonite & 2.7 & 2.0 \\
\hline
\end{tabular}

Table 2. Changes in pore volume of flow after 15 months of distilled water and leachate permeation (Francisca \& Glatstein, 2010) 
Results of hydraulic conductivity test after long term permeation of the tested samples with distilled water and leachate conducted by Francisca \& Glatstein (2010) are presented in Fig 4. The decrease of water permeability of the tested soils after 15 months of leachate treatment is visible in case of $0 \%$ and $5 \%$ bentonite content. The reported changes in soil water conductivity, according to the paper, could have resulted from expansion/shrinking of expansive minerals, mineral clogging and bioactivity - the mechanism of ion exchange and reduction of double-layer thickness which should increase the water permeability has in this case a negligible effect.

\section{Hydraulic conductivity}
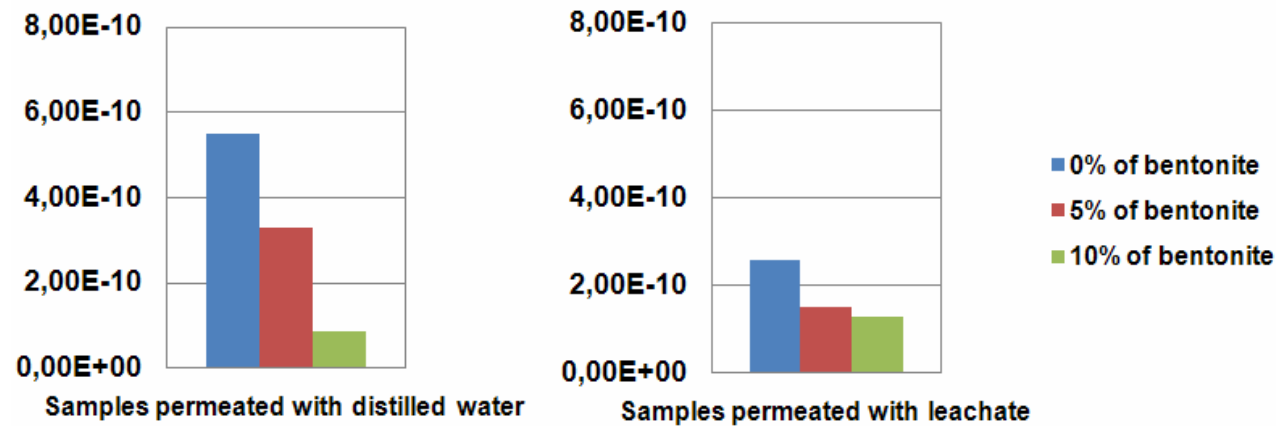

Fig. 4. Hydraulic conductivity $\mathrm{k}\left(\mathrm{m} \cdot \mathrm{s}^{-1}\right)$ of compacted silt with bentonite amendments (based on data of Francisca \& Glatstein, 2010)

Several studies were focused on determination of leachate effect on geosynthetic materials applied in construction of landfill bottom liner - usually geosynthetic clay liners (GCLs) used as hydraulic barrier in landfills, remediation sites or other contamination systems. Shan and Lai (2002) tested the hydraulic conductivity of two different geosynthetic liners: Bentomat ST and Claymax 200R, CETCO, USA, using different liquids as penetrating medium. Both tested GCLs were approx. $6 \mathrm{~mm}$ thick and both contained bentonite in the amount of $3.6 \mathrm{~kg} / \mathrm{m}^{2}$. The hydraulic conductivity tests were conducted according to standard ASTM D5887 procedure at effective pressure of $34.5 \mathrm{kPa}$ with typical time of hydration equal to 48 hours (7 days for tap water). The trials of sequential permeation by water and then by leachate were also conduced. The results of the measurements conducted by Shan and Lai (2002) are presented in Table 3.

\begin{tabular}{|l|c|c|}
\hline \multirow{2}{*}{ Permeate } & \multicolumn{2}{|c|}{ Hydraulic conductivity [m.s $\left.\mathrm{s}^{-1}\right]$} \\
\cline { 2 - 3 } & Bentomat ST & Claymax 200R \\
\hline Deionized distilled water & $2.7 \cdot 10^{-11}$ & $2.7 \cdot 10^{-11}$ \\
\hline Tap water & $4.4 \cdot 10^{-11}$ & $4.8 \cdot 10^{-11}$ \\
\hline Landfill leachate & $3.0 \cdot 10^{-11}$ & $2.6 \cdot 10^{-11}$ \\
\hline Tap water $\rightarrow$ leachate & $3.7 \cdot 10^{-11}$ & $1.9 \cdot 10^{-11}$ \\
\hline
\end{tabular}

Table 3. Hydraulic conductivity of two types of geosynthetic clay liners (Shan \& Lai, 2002).

Both materials showed the same value of water permeability for deionized distilled water and higher values for tap water; the observed increase reaching approx. $70 \%$. Application of 
landfill leachate as a permeate caused a decrease of GCLs water conductivity for both materials of approx. $31,8 \%$ and $84.6 \%$ in comparison to water conductivity for tap water. Then, sequential tests of permeation by tap water and then by leachate showed a decrease of hydraulic conductivity of the studied geosynthetics by, respectively, $15,9 \%$ and $60,4 \%$ in comparison to results obtained for tap water only.

\begin{tabular}{|l|l|l|l|}
\hline \multicolumn{1}{|c|}{ Material } & \multicolumn{1}{|c|}{$\begin{array}{c}\text { Direction of changes } \\
\text { of permeability }\end{array}$} & $\begin{array}{c}\text { Reference } \\
\text { liquid }\end{array}$ & \multicolumn{1}{c|}{ Source } \\
\hline Natural clay of a landfill & $\begin{array}{l}\text { Little increase, 3-4 weeks } \\
\text { test }\end{array}$ & water & $\begin{array}{l}\text { Ozcoban et al., } \\
2006\end{array}$ \\
\hline $\begin{array}{l}\text { Lateric Indian soil of an } \\
\text { open damp }\end{array}$ & $\begin{array}{l}\text { Up to 50\% increase of } \\
\text { permeability with } \\
5-20 \% \text { leachate in water }\end{array}$ & water & Nayak et al., 2007 \\
\hline $\begin{array}{l}\text { Silt soil with 5 and 10\% } \\
\text { of bentonite }\end{array}$ & Decrease, 15 month test & $\begin{array}{l}\text { distilled } \\
\text { water }\end{array}$ & $\begin{array}{l}\text { Francisca \& } \\
\text { Glatstein, 2010 }\end{array}$ \\
\hline Two geosynthetic liners & Decrease & tap water & Shan \& Lai, 2002 \\
\hline
\end{tabular}

Table 4. A summary of the effect of landfill leachate on hydraulic permeability of selected materials (as compared to water) according to different sources.

Summing up we may state that cited, exemplary reports show different effects of leachate on saturated conductivity of landfill liner materials (Table 4). It should be emphasized that there no data related to the action time of many years, as the longest test did not exceed 15 months (Francisca \& Glatstein, 2010). It should be added that hydraulic conductivity may change due to modification of soil water repellency by leachates (cf. Hartman et al., 2010).

\section{Amendments used to improve hydromechanical properties of liners}

In many cases hydraulic permeability of local soils may be insufficient even after application of external loads leading to compaction (e.g. Bogchi, 2004). An example of such situation is a silty soil from Chaco - Pampean plain in the center and north- east of Argentina covering $600000 \mathrm{~km}{ }^{2}$ characterized by mean hydraulic conductivity $10^{-8} \mathrm{~m} \cdot \mathrm{s}^{-1}$ after compaction (Francisca \& Glatstein, 2010). Thus this material requires modification in order to be useful for landfill liner construction.

Numerous researches, presented in Table 5, reported different attempts of decreasing water hydraulic permeability of various materials by application of series of amendments to meet the required threshold values. This Table shows that among many materials tested, bentonite shows high popularity. Bentonite is a natural clay characterized by a very high swelling capacity, high ion exchange capacity and very low value of water permeability. The most important characteristics of bentonites are high montmorillonite content (60-90\%), high water absorption capacity (200-700\% weight), swelling volume of 7-30 ml, pH suspension value $9-10.5$, plasticity $140-380 \%$, and cation exchange capacity $0.60-0.90 \mathrm{~mol} / \mathrm{kg}$ (Egloffstein, 2001).

From other materials we should mention claystones, natural zeolites, fly ashes, water glass, silica fume, cement and some other waste materials (see below). A special attention deserves quick lime $(\mathrm{CaO})$ which can be used to reduce water content of the material during compaction and to stabilize the liner structure (eg. Wiśniewska \& Stępniewski, 2007). 


\begin{tabular}{|c|c|c|c|}
\hline Material & Description & $\begin{array}{l}\text { Minimal reported } \\
\mathrm{k}: \mathrm{m} \cdot \mathrm{s}^{-1}\end{array}$ & Sources \\
\hline \multirow[b]{2}{*}{ Fly ash } & $\begin{array}{l}\text { Ash from incineration plant, sewed }<4 \\
\text { mm, mixed with Freidland clay }\end{array}$ & No data & $\begin{array}{l}\text { Travar et al., } \\
2009\end{array}$ \\
\hline & $\begin{array}{l}\text { C type fly ashes generated in } \\
\text { Columbia Generating Station Unit II, } \\
\text { Portage, Wisconsin added in } 28 \% \text { to } \\
\text { sand and bottom ash, compacted at } \\
18 \% \text { water content }\end{array}$ & $3.1 \cdot 10^{-10}$ & $\begin{array}{l}\text { Palmer et al., } \\
2000\end{array}$ \\
\hline $\begin{array}{l}\text { Quicklime } \\
\text { and water } \\
\text { glass }\end{array}$ & $\begin{array}{l}\text { Waste rock of coal mine (Bogdanka, } \\
\text { Poland), mixed with } 2 \% \text { (by mass) of } \\
\text { quicklime }(\mathrm{CaO}) \text { and } 6 \% \text { by mass of } \\
\text { water-glass. }\end{array}$ & $1 \cdot 10^{-10}$ & $\begin{array}{l}\text { Wiśniewska } \\
\& \\
\text { Stępniewski, } \\
2007\end{array}$ \\
\hline Silica fume & $\begin{array}{l}\text { Silica fume from Ferro-Chromite } \\
\text { Factory in Antalya, Turkey mixed in } \\
\text { different proportion with natural clays } \\
\text { of clay pit in Oltu, Turkey. }\end{array}$ & $\begin{array}{l}\text { 9,03.10-10 for } 25 \% \text { of } \\
\text { silica fume* }\end{array}$ & $\begin{array}{l}\text { Kalkan \& } \\
\text { Akbulut, } \\
2004\end{array}$ \\
\hline \multirow{5}{*}{ Bentonite } & $\begin{array}{l}\text { Japanese commercial bentonite } \\
\text { Kunigel-V1 extracted from Tsukinuno } \\
\text { Mine, Japan, mixed with sand }\end{array}$ & 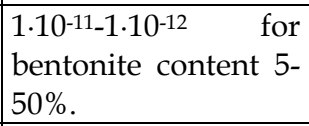 & $\begin{array}{l}\text { Komine } \\
2004,2010\end{array}$ \\
\hline & $\begin{array}{l}\text { Bentonite of } 92 \% \text { sodium } \\
\text { montmorillonite (by Minarmco SA) } \\
\text { added to Chaco-Pampean silt in the } \\
\text { amount of } 5 \text { and } 10 \% \text {. }\end{array}$ & $\begin{array}{|llr|}3.3 \cdot 10^{-10} & - & 5 \% \\
\text { bentonite } & & \\
8.5 \cdot 10^{-11} & - & 10 \% \\
\text { bentonite } & & \\
\end{array}$ & $\begin{array}{l}\text { Francisca \& } \\
\text { Glatstein, } \\
2010\end{array}$ \\
\hline & $\begin{array}{l}\text { Compacted sodium and calcium } \\
\text { exchanged bentonite, Gyungsang, } \\
\text { Korea }\end{array}$ & $\begin{array}{|lll|}\begin{array}{l}5.4 \cdot 10^{-12} \\
\text { bentonite }\end{array} & \text { for } & \mathrm{Ca} \\
9.9 \cdot 10^{-12} & \text { for } & \mathrm{Na} \\
\text { bentonite } & & \\
\end{array}$ & $\begin{array}{l}\text { Ahn \& Jo, } \\
2009\end{array}$ \\
\hline & $\begin{array}{l}\text { Bentonite compacted (intermediate } \\
\text { and modified by Proctor test) different } \\
\text { shapes and sizes commercial gravel } \\
\text { particles by AquaBlok, Ltd. }\end{array}$ & $\begin{array}{l}6.08 \cdot 10^{-12} \\
\text { (intermediate } \\
\text { Proctor) } \\
5.98 \cdot 10^{-12} \quad \text { (modified } \\
\text { Proctor) } \\
\end{array}$ & $\begin{array}{l}\text { Roberts \& } \\
\text { Shimanoka, } \\
2008\end{array}$ \\
\hline & $\begin{array}{l}\text { Commercial Na-bentonite and Ca- } \\
\text { bentonite (Concarde Mining) mixed } \\
\text { with crushed, natural zeolites } \\
\text { (Etibank-Bigadic, Turkey) at different } \\
\text { proportions }\end{array}$ & $5 \cdot 10^{-10-8 \cdot 10-10}$ & $\begin{array}{l}\text { Kaya \& \& } \\
\text { Dudukan, } \\
2004\end{array}$ \\
\hline \multirow{2}{*}{$\begin{array}{l}\text { Geosynthetic } \\
\text { clay liners } \\
(\mathrm{GCL})\end{array}$} & $\begin{array}{l}\text { A thin layer of sodium or calcium } \\
\text { bentonite bonded to a layer or layers of } \\
\text { geosynthetic }\end{array}$ & \begin{tabular}{|lr}
$2 \cdot 10^{-10}-2 \cdot 10^{-12}$ & \\
depending & on \\
confining & stress \\
(general info) & \\
\end{tabular} & $\begin{array}{l}\text { Bouazza, } \\
2002\end{array}$ \\
\hline & $\begin{array}{l}\text { Bentonite based medium-heavy and } \\
\text { heavy GCL, after ion exchange in situ } \\
\text { for 1-3 years }\end{array}$ & $\begin{array}{l}1 \cdot 10^{-10}-1 \cdot 10^{-11} \\
\text { permeability } \\
\text { increased during } \\
\text { observation period }\end{array}$ & $\begin{array}{l}\text { Egloffstein, } \\
2001\end{array}$ \\
\hline
\end{tabular}




\begin{tabular}{|c|c|c|c|}
\hline Material & Description & $\begin{array}{l}\text { Minimal reported } \\
\mathrm{k}: \mathrm{m} \cdot \mathrm{s}^{-1}\end{array}$ & Sources \\
\hline $\begin{array}{l}\text { Geosynthetic } \\
\text { clay liners } \\
(\mathrm{GCL})\end{array}$ & $\begin{array}{l}\text { Modification of commercial GCL } \\
\text { Claymax 200R (CETCO, USA: layer of } \\
\text { bentonite between two polypropylene } \\
\text { geotextiles) - GCL was modified by } \\
\text { standard bentonite with HDTMA- } \\
\text { bentonite or BTEA bentonite sprayed } \\
\text { instead upper geotextile. }\end{array}$ & $\begin{array}{l}\text { 6.8 } \cdot 10^{-11} \text { - unaltered } \\
\text { Claymax 200R } \\
1.2 \cdot 10^{-10 ~-~} 30 \% \\
\text { BTEA-bentonite } \\
3.4 \cdot 10^{-11}-30 \% \\
\text { HDTMA-bentonite }\end{array}$ & $\begin{array}{l}\text { Lorenzetti et } \\
\text { al., } 2005\end{array}$ \\
\hline Cement & $\begin{array}{l}\text { Askale Cement Factory, Erzurum, } \\
\text { Turkey, mixed with Oltu - Erzurum } \\
\text { (Turkey) clay. }\end{array}$ & $8.53 \cdot 10^{-10}$ & Kalkan, 2006 \\
\hline Claystone & $\begin{array}{l}\text { Northpatagonian smectite rich } \\
\text { claystones mixed with sand - } 15 \% \text { of } \\
\text { claystones }\end{array}$ & $5.34 \cdot 10^{-12}$ & $\begin{array}{l}\text { Musso et al., } \\
2010\end{array}$ \\
\hline Red mud & $\begin{array}{l}\text { By product of the caustic leaching of } \\
\text { bauxite to produce alumina, redish- } \\
\text { brown color, superfine particle-size } \\
\text { distribution, mixed with Oltu - } \\
\text { Erzurum, Turkey clay and Askale } \\
\text { Cement Factory, Erzurum, Turkey } \\
\text { cement in different proportions. }\end{array}$ & $3.73 \cdot 10^{-10}$ & Kalkan, 2006 \\
\hline Rubber & $\begin{array}{l}\text { Pulverized form of tires rubber added } \\
\text { to mixture of C type fly ash }(90 \%) \text { by } \\
\text { Soma thermal power plant, Turke and } \\
\text { bentonite. }\end{array}$ & $\begin{array}{l}9.5 \cdot 10^{-12} \text { after } 0 \text { days } \\
2.7 \cdot 10^{-11} \text { after } 28 \\
\text { days Both for } 90 \% \\
\text { fly ash, } 3 \% \text { rubber } \\
\text { and } 7 \% \text { of bentonite } \\
\text { content. }\end{array}$ & $\begin{array}{l}\text { Cokca } \& \\
\text { Yilmaz, } 2004\end{array}$ \\
\hline
\end{tabular}

${ }^{*}$ Normalized permeability $=k_{\exp }\left(\rho_{\text {std }} / \gamma_{\text {dmax }}\right)-$ where: $\rho_{\text {std }}$ is the standard value of specific gravity adopted by the Authors as 2.65; $\gamma_{\mathrm{dmax}}$ - maximum dry bulk density of the sample.

Table 5. Various amendments applied to lower the water permeability of different materials likely to be used for construction of landfill liners (according to different sources).

\section{Capillary barrier concept and landfill liner construction}

\subsection{Introduction}

Recently the capillary barrier system is more often applied because the natural soil behaviour concerning water fluxes and direction of fluxes underlines the long term efficiency of layered systems for multidimensional water transport. It is well known, that soils are highly heterogeneous and anisotropic materials because a myriad of processes influence the formation of physical structure with time. A major impact influencing the soil structure during the preparation of waste deposit capping systems occurs due to machinery application through compaction, mixing and a degeneration of processes that thereafter again promote aggregation (Ahuja et al., 1984). One property that is highly sensitive to all changes in particle arrangements and structure formation due to physical, chemical and anthropogenic processes is the conductivity of pores, which as Bear (1972) mentioned is 
strongly influenced by pore-geometric factors, like total porosity, pore-size distribution, shape of the pore system, continuity and tortuosity. Normal swelling and shrinkage processes, especially in clayey, silty, and loamy soils result in the formation of direction dependent secondary pores and aggregate shapes. The same is also true when soils are loaded (as can be also proved e.g. by the tillage-induced plough pan), which alters pore geometries affecting the air and water-filled pores and, consequently their functionality. Thus, the development of soil structure can be evaluated through the presence of a direction-dependent behavior of hydraulic properties. These properties present anisotropy if they are direction dependent, otherwise they would be considered as isotropic.

The development or the preparation of soil structure or various layers most often reveals anisotropy. Stratified soils, consisting of fine layers parallel to the surface, exhibit a dominant horizontal component of the saturated hydraulic conductivity $\left(\mathrm{k}_{\mathrm{sh}}\right)$ greater than its vertical component $\left(\mathrm{k}_{\mathrm{sv}}\right)$ (Mualem, 1984; Tigges, 2000). Under unsaturated conditions, the direction dependent hydraulic fluxes can either be also anisotropic in horizontal or vertical direction or they can also for a certain matrix potential range becoming isotropic. Single soil horizons also present anisotropy, which can be also used to define the aggregate formation theory and to quantify the consequences for the $3 \mathrm{~d}$ effects on water fluxes. Consequently these functions can be furthermore broadened if during the construction of capping systems a defined layering is achieved in order to e.g. support long-term impermeability of such capping systems (Hartmann et al., 2009; Horn et al., 2001). In the following the consequences of direction-dependent behavior on mass transport at the scale of soil horizons or soil layers will be defined in order to also evaluate the consequences for water movement on the waste deposit scale. However, it must be also stated that the anisotropy or isotropy depends on the drying history, too, which underlines that in order to really predict the 3D water fluxes a very detailed analysis of the hydraulic properties must be done. Thus, the anisotropic behavior of hydraulic conductivity plays an important role in the analysis and modeling of transport processes in soils, especially in heterogeneous soils conducting water or chemicals in 2 and 3 dimensions.

\subsection{Physical principles}

Irrespective of the material, any kind of mass movement always occurs in the direction of the steepest slope and depends on the conductivity and gradient dependent flux. Considering the theoretical background, the hydraulic conductivity/matrix potential functions are to be defined as vectors which are described in the complete form of the Laplace equation for multidimensional water flux where the hydraulic conductivity /matrix potential relation has to be included for the $x, y, z$, directions as soon as $k_{x} \neq k_{y} \neq k_{z}$. This boundary condition is in general to be accepted if we deal with non equally sized spheres, which in addition have not reached the smallest possible pore volume or maximum amount of contact points. It therefore also requires more consideration for sampling and, in the consequence, it also has to be included in all discussions dealing with mass movement in systems under a given slope as well as it affects the construction of layered capping sealing systems concerning the mass flow of water and sediments along the slope line. Additionally it also has implications for the reformation of structure elements if especially swell/shrink processes and gravitational forces result in crack formation in the freshly compacted soil layers at a water content higher than that at the Proctor density. 


\subsection{Hydraulic properties of layered soils}

\subsubsection{Effect of pore size distribution, water saturation, and pore connectivity}

Water content / matrix potential functions define the pore size distribution which gives an insight in the ratio of the volume of pores related to the volume of the bulk soil. The coarser the soil the better aerated, the finer the pores the less aerated and the longer remains the water in these pores. Aggregate formation, anthropogenic effects result in an intense change in the pore diameter as well as in the total porosity, which also causes interruptions between different soil layers and can also cause stagnant water (=stagnic soil properties) or altered water flow intensity and directions (for more detailed info see Gräsle et al., 1995; Nielsen \& Kutilek 1995).

\subsubsection{Effect of hydraulic conductivity/matrix potential ratio}

Apart from the pore size distribution we need a better insight in the water flux properties because they primarily define the transport within the soils. It is well known that under saturated conditions coarse textured soils with the dominance of coarse pores have a high saturated flow rate (=saturated hydraulic conductivity), while in soils with dominating medium and fine pores the saturated hydraulic conductivity gets smaller. Under unsaturated conditions however, samples with more medium and fine pores keep their unsaturated hydraulic conductivity the longer the smaller the pores are while coarse pores are emptied very quickly. Consequently the remaining hydraulic conductivity is intensely reduced (Fig. 5). Between the curves of 2 materials we can define the cross over suction value, which defines the $\mathrm{pF}$ value at which both materials have an identical hydraulic conductivity. If the soil dries out more intensely the finer textured soil with the higher amount of finer pores has a higher hydraulic conductivity, while left from this point more water flows in the coarser textured material.

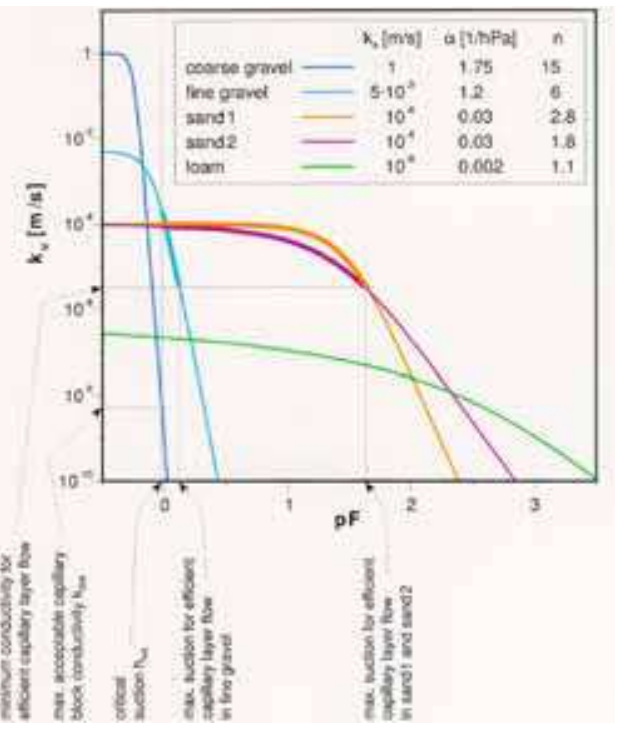

Fig. 5. Hydraulic conductivity versus matrix potential (defined as $\mathrm{pF}$ value) for very coarse up to finer textured soils. 
The cross over suction value (Hillel, 1998) defines the matrix potential or $\mathrm{pF}$ value where the hydraulic properties of the various materials are identical. Thus, if we now come back to a very old picture of W. Gardner, (Washington State University, USA) the consequences for the water flow in layered systems can be easily understood. In this example (Fig. 6) he prepared a layered sample with fine over coarse sand and proved that at $\mathrm{t} 1$ the water mostly flows downwards, at $\mathrm{t} 2$ the water front concentrates at the boundary (=coarser) layer until the water content is increased sufficiently and the matrix potential declined. At $\mathrm{t} 3$ the matrix potential in the top layer gets sufficiently high, which results in a pronounced vertical infiltration in the coarser lower layer.

t1

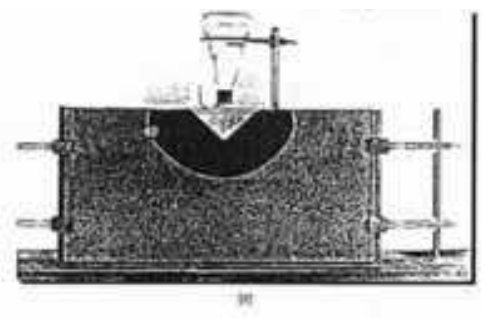

t2

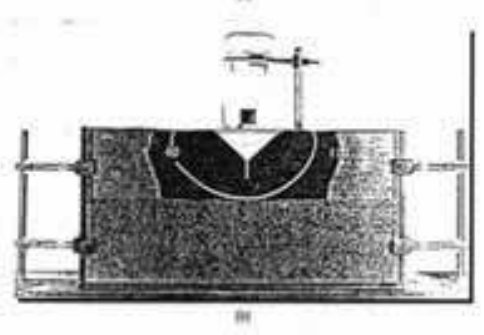

t3

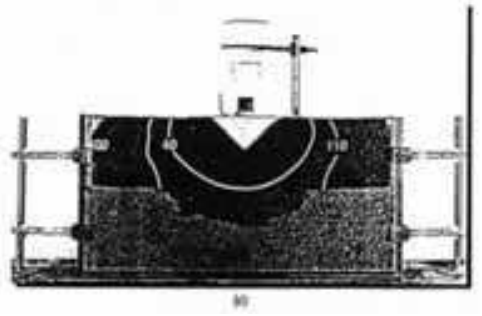

Fig. 6. Downward water movement in a layered sand tank as a function of time: the top layer consists of finer sand and the bottom one of coarser sand. (Picture originates from W.H. Gardner, Washington State University, USA). At $\mathrm{t} 1$ the water mostly flows downwards, at $\mathrm{t} 2$ the water front concentrates at the boundary (=coarser) layer until the water content is increased sufficiently and the matrix potential declined. At $t 3$ the matrix potential in the top layer gets sufficiently high, which results in a pronounced vertical infiltration in the coarser lower layer.

\subsection{Application of the anisotropy principle to the capillary barrier concept}

The capillary barrier concept requests the defined construction of the various layers in dependence of the expected climatic conditions and on the later land use (Fig. 7). On top of the waste body and the compensation layer, the capillary block contains coarse textured 
material (e.g. gravel) with very coarse pores which are emptied immediately when even only a very small unsaturation degree is reached. Thereafter follows the capillary layer which consists of finer material like fine sand. Finally, a recultivation soil layer ensures the storage of sufficient plant available water, nutrient storage and rootability and guarantees a mostly rigid i.e. long term stable topsoil.

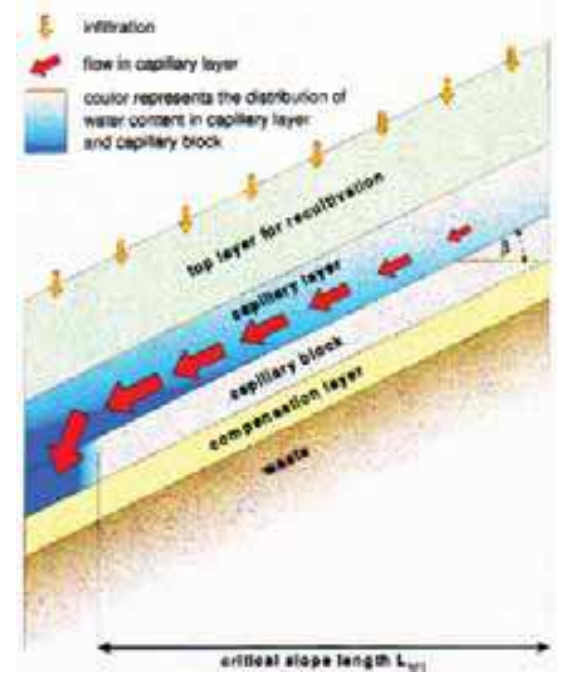

Fig. 7. Construction of waste capping systems applying the concept of capillary barrier

Consequently, the capillary barrier system can be ranked as an waste deposit sealing system, which facilitates not only the reuse of soils available in the region if their physical properties are known. If the above defined principles are agreed it becomes obvious that in order to also quantify the lateral fluxes the tensorial functions of the hydraulic conductivity can be used to construct an impermeable and long- term stable capping system (Horn, 2002; Baumgartl et al., 2004).

\subsection{Example: two dimensional hydraulic fluxes in a layered waste deposit capping system (Rastorf, Germany)}

Based on the hydraulic conductivity and continuous matrix potential measurements the 2 dimensional fluxes within the topsoil waste deposit capping system (Figs. 8-10) could be verified (Hartmann et al., 2009).

It become obvious that the flow direction as well as the dynamics of the changes between vertical upwards, downwards or lateral flow can be quantified and always related to the present situation of the matrix potential dependent hydraulic conductivity for the various layers. In case of the upwards flow, the drying intensity of the topsoil layer was high and caused the capillary rise (Fig 8) while in Fig. 9 the hydraulic conductivity of the topsoil was much higher than that of the coarser layer below. However, even if the re-saturation results in less negative matrix potential values in the finer topsoil and the coarser subsoil layer is left of the cross over suction value and a vertical downward water movement occurs it is still reversing as soon as the soil layers dry out again. Thus, such layering can be classified as a long- term stable system with a self "reparing= reversing” flux system. 


\section{Simulation}

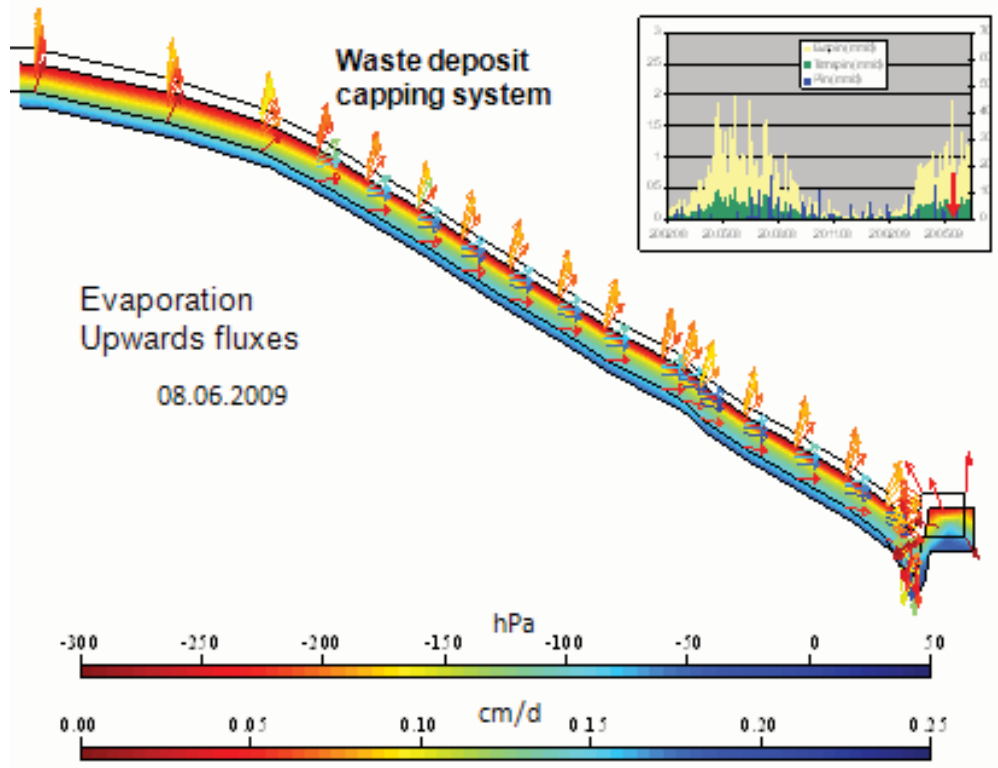

Fig. 8. Simulated hydraulic fluxes in a waste deposit capping system: the case presents situation with dominant upwards flow.

\section{Smulation}

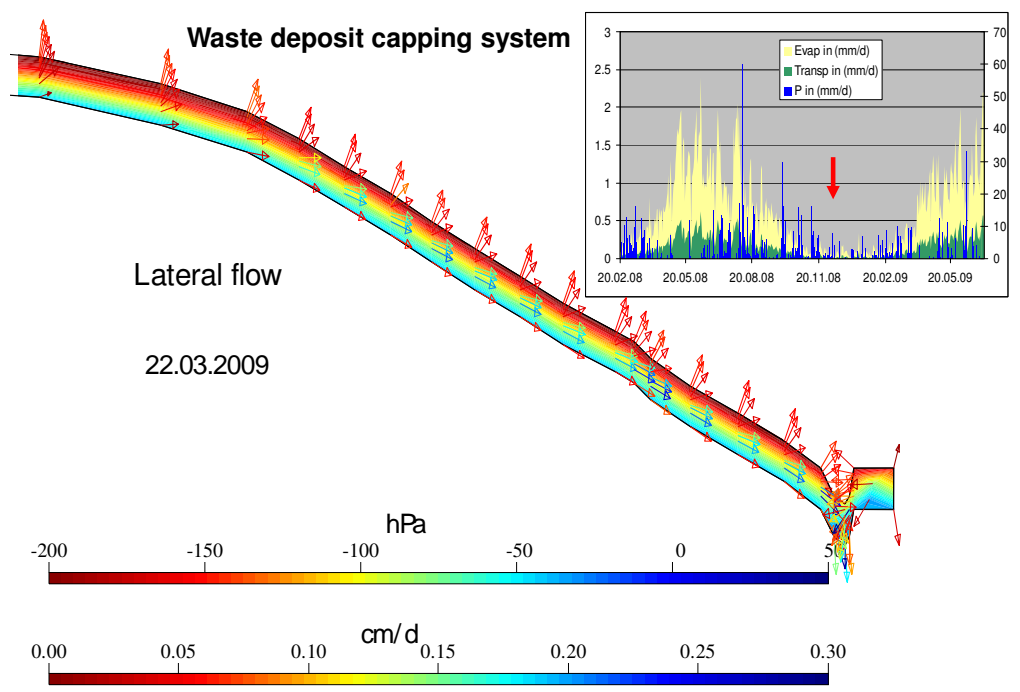

Fig. 9. Simulated hydraulic fluxes in a waste deposit capping system with the lateral flow situation 


\section{Smulation}

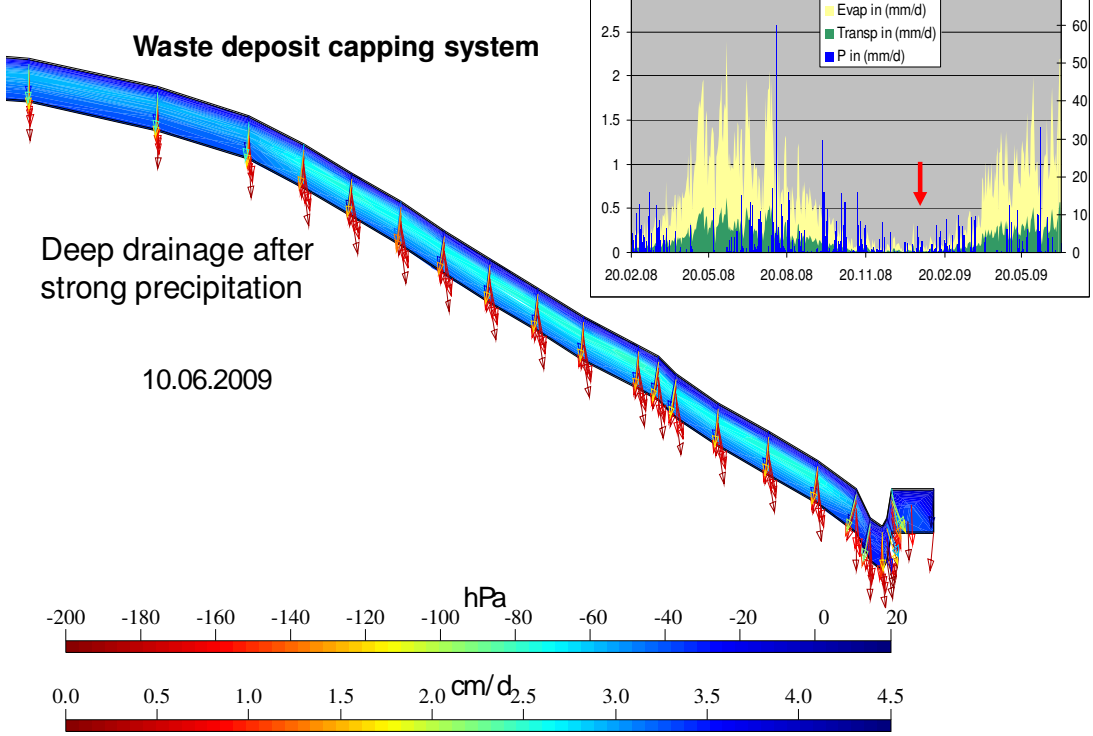

Fig. 10. Simulated hydraulic fluxes in a waste deposit capping system: an example of short term deep drainage in case of a heavy rainfall event.

\section{Conclusions}

Hydraulic conductivity is a key factor for landfill construction. In the case of bottom liner it is the matter of sufficiently low saturated hydraulic conductivity and long - term stability in time. In case of top capping the situation is much more complicated as problem of removal of infiltrating rain water and presence of soil recultivation layer are involved.

In this case the impermeability is always proved as long as the cross over suction value between the hydraulic conductivity/matric potential relationships of the two layers under consideration is exceeded in all directions for the underlying soil layer. Under those boundary conditions the lateral movement of water is guaranteed also in structured soils. It must be underlined that the anisotropy depends always on the mechanical or hydraulic prestresses which coincides with a strong control need of these hydraulic or mechanical stresses.

Anisotropy of hydraulic conductivity is also proved for the unsaturated state and its consideration results in a better validation of modeled versus measured water fluxes on all scales.

\section{References}

Ahmed, M., (2008). Improvement of solid waste disposal facilities at Matuail in Dhaka City. Proceedings of the National Seminar on Solid Waste Management - WasteSafe, Khulna, Bangladesh 1-12 
Ahn, H.-S. \& Jo, H.Y., (2009). Influence of exchangeable cations on hydraulic conductivity of compacted bentonite. Applied Clay Science 44, 144-150

Ahuja, L.R., Naney, J.W., Green, R.E. \& Nielsen, D.R. (1984): Macroporosity to characterize spatial variability of hydraulic conductivity and effects of land management. Soil Sci. Soc. Am. J. 48, 699 - 702.

Alamgir, M., McDonald, Ch., Roehl, K.E., Ahsan A. (Eds.) (2005). Integrated Management and Safe Disposal of Municipal Solid Waste in Least Deveoped Asian Countries. A Feasibility Study. p 83. Khulna University of Engineering and Technology, Khulna, Bangladesh.

Albrecht, K.A. \& Cartwright, K., (1989). Infiltration and hydraulic conductivity of a compacted earthen liner. Groundwater 27 (1), 14-19.

Bagchi, A., (2004). Design of landfills and integrated solid waste management. John Wiley and Sons Inc. Hoboken. New Jersey.

Baumgartl, T., Horn, R., Richards, B.G., (2004). Soil physical processes in capping systems of landfills - possibilities of capillary break capping. 277 - 288. in: Juhasz,A.L., G.Magesan, R.Naidu (eds) Waste Management, Science Publ. ISBN: 1-57808-323-0

Bear, J., (1972). Dynamics of Fluids in Porous Media. Elsevier, New York, p. 764. [4]

Benson, C.H., Trast, J.M., (1995). Hydraulic conductivity of thirteen compacted clays. Clays and Clay Minerals 43 (6), 669-681

Bouazza, A., (2002). Geosynthetic clay liners. Geotextiles and Geomembranes 20. 3-17

Brovelli, A., Malagureea, \& Barry D.A., (2009). Bioclogging in porous media: Model development and sensitivity to initial conditions. Environmental Modelling \& Software, 24, 611-626.

Cokca, E. \& Yilmaz, Z., (2004). Use of rubber and bentonite added fly ash as a liner material. Waste Management 24. 153-164

Darcy, H., (1856). Les fontaines publiques de la vill de Dijon. Paris, Dalmont.

Dexter, A.R., Czyz, E.A. \& Gate, O.P., (2004). Soil structure and the saturated hydraulic conductivity of subsoils. Soil \& Tillage Research 79. 185-189

Di Iaconi C., Pagano M, Ramadori R., \& Lopez A. (2010). Nitrogen recovery from a stabilized municipal landfill leachate. Bioresource Technology 101, 1732-1736

EEA (2004). Waste and Material Flows 2004. European Topic Centre on Waste and Material Flows. European Environmental Agency, Copenhagen, 76 p.

EU (1999). Landfill directive: Council Directive 1999/31/EC of 26 April 1999 on the landfill of waste. Official Journal of the European Communities. L182, 1-19.

Egloffstein, T.A., (2001). Natural bentonites-influence of the ion exchange capacity and partial desiccation on permeability and self-healing capacity of bentonites used in GCLs. Geotextiles and Geomembranes, 19, 427- 444.

Ehrig, H., (1989). Leachate quality. In: Christensen, T.H., Cossu, R.,Stegmann, R. (Eds.), Sanitary Landfilling: Process, Technology, and Environmental Impact, Academic Press, London, pp. 213-229

Fatta, D., Voscos, C., Papadopoulos, A., Loizidou, M.,( 1998). Leachate quality of a MSW landfill. Journal Environmental Science and Health Part A A33 (5), 749-763

Flowers, M.D. \& Lal, R., (1998). Axle load and tillage effects on soil physical properties and soybean grain yield on a mollic ochraqualf in northwest Ohio. Soil Till. Res. 48, 2135 
Foged, N. \& Baumann, J., (1999). Clay membrane made of natural plasticity clay: leachate migration due to advection and diffusion. Engieneering Geology, 54, 129 - 137.

Francisca, F.M. \& Glatstein, D.A. (2010). Long term hydraulic conductivity of compacted soils permeated with landfill leachate. Applied Clay Science 49. 187-193

Gardner, W.H. Washington State University. USA. Private communication.

Gräsle, W., Richards, B.G., Baumgartl, T. \& Horn R., (1995): Interaction between soil mechanical properties of structured soils and hydraulic processes- theoretical fundamentals of a model. 719 - 725, in: Alonso E.E. \& Delage P. (eds.) Unsaturated soils. Balkema Verlag ISBN: 9054105844

Gunarathna, H.A.Y.R., Kapukotuwa, A.S.B., Karunarathna, A.K. \& Basnayake, B.F.A. (2007). Construction and Evaluation of a Low Cost, Waste Polyethylene Based Liner for Small Landfills. Proceedings of the International Conference on Sustainable Solid Waste Management, Chennai, India. pp.226-233

Hartmann ,P., Fleige, H., Horn, R. (2010). Water repellency of fly ash- enriched forest soil from eastern Germany. Europ. J. Soil Sci. 61,107-1078.

Hartmann, P., Gebhardt, S., Janßen,I., Fleige,H., Horn,R. (2009). Auswirkungen des Klimawandels auf die Gestaltung von geschichteten mineralischen Abdeckungssystemen von Deponien. Abschluss und Rekultivierung von Deponien und Altlasten: Egloffstein und Burghardt (Hrsg) : 17, 207-217, ISBN: 978-3-93966206-8, ICP Eigenverlag Bauen und Umwelt

Hillel, D., (1998). Environmental Soil Physics. Lewis Publ.

Horn, R., (2002). Analysis of drying processes of mineral capping material. (in German, with English summary and captures) Analyse des Austrocknungsverhaltens von mineralischem Bodenmaterial anhand von Laboruntersuchungen. Ed.: Ramke W.G.e.a., Höxter, Höxteraner Berichte zu angewandten Umweltwissenschaften, 3, 269-278

Horn, R., (2004). Recommendations for the preparation of no shrinking mineral liner systems (in German with English summary and captions) Empfehlungen zur Herstellung nicht schrumpfanfälliger mineralischer Dichtungen mit zusätzlicher tonmineralischer Wasserspeicherschicht für Deponie- ober flächen abdichtung systeme. Müll und Abfall 36, 67-71

Horn R., Baumgartl, T., Possel, H., Koselowske, M., Albiker, B., (2001). Waste deposit sealing systems with mineral materials- a long term impermeable alternative? (in German, with English summary and captures) Deponieabdichtungen aus mineralischem Material - eine undurchlässige Langzeitperspektive? Wasser and Abfall, 3,38 - 41,

Horn, R. \& Stępniewski, W., (2004). Modification of mineral liner to improve its long term stability. Int. Agrophysics 18 317-323

Islam, M.R., Alamgir, M., Mohiuddin, K.M. \& Hasan, K.M.M. (2008). Investigation of physical properties of a selected soil to use as a compacted clay liner in sanitary landfill. Proceedings of the National Seminar on Solid Waste Management WasteSafe 2008, Khulna, Bangladesh 167-174

Junge, T., Thienemann, J., Gräsle, W., Baumgartl, T. \& Horn R., (1997): Effect of mechanical and hydraulic stresses on the long term stability of waste deposits. (in German, with an English abstract and figure captures). Müll and Abfall 8, 475 - 478

Junge, T., Gräsle, W., Bensel, G. \& Horn, R., (2000). Effect of pore water pressure on tensile strength. Z. Pflanzenernährung und Bodenkunde, 163, 21 - 27 
Kalkan, E., (2006). Utilization of red mud as a stabilization material for the preparation of clay liners. Engineering Geology 87. 220-229

Kalkan, E. \& Akbulut S., (2004). The positive effects of silica fume on the permeability, swelling pressure and compressive strength of natural clay liners. Engineering Geology 73. 145-156

Kaya, A. \& Durukan, S. (2004). Utilization of bentonite-embedded zeolite as clay liner. Applied Clay Science 25. 83- 91.

Kjeldsen, P., Christoffersen, M., (2001). Composition of leachate from old landfills in Denmark. Waste Management and Research 19, 249-256.

Komine, H., (2004). Simplified evaluation on hydraulic conductivities of sand-bentonite mixture backfill. Applied Clay Science 26. 13-1.

Komine, H., (2010). Predicting hydraulic conductivity of sand-bentonite mixture backfill before and after swelling deformation for underground disposal of radioactive wastes. Engineering Geology 114. 123-134.

Kooistra, J.M., Tovey, N.K., (1994). Effects of compaction on soil microstructure. In: Soane, B.D., van Quwerkerk, C. (Eds.), Soil Compaction in Crop Production. Elsevier Science (Chapter 5), pp. 91-111

Kulikowska, D. \& Klimiuk, E. (2008). The effect of landfill age on municipal leachate composition. Bioresource Technology 99. 5981-5985

Kylefors, K., (2003). Evaluation of leachate composition by multivariate data analysis (MVDA). Journal of Environmental Management 68. 367-376

Lorenzetti, R.J., Bartelt-Hunt, S.L., Burns, S.E. \& Smith, J.A., (2005). Hydraulic conductivities and effective diffusion coefficients of geosynthetic clay liners with organobentonite amendments. Geotextiles and Geomembranes 23.385-400

Mitchell, J.K., Jaber, M., (1990). Factors controlling the long-term properties of clay liners. Waste containment systems: construction, regulation and performance. ASCE. Geotechnical Special Publication 26, 84-105

Mitchell, J.K., Soga, K., (2005). Fundamentals of Soil Behavior, 3rd Edition. John Wiley \& Sons, Hoboken.

Mualem, Y., (1984): Anisotropy of unsaturated soils. Soil Sci. Soc. Am. J. 48, 505-509.

Musso, T.B., Roehl, K.E., Pettinari, G. \& Vallés, J.M., (2010). Assessment of smectite-rich claystones from Northpatagonia for their use as liner materials in landfills. Applied Clay Science 48 (2010) 438-445

Nakano, K. \& Miyazaki, T., (2005). Predicting the saturated hydraulic conductivity of compacted subsoils using the non-similar media concept. Soil \& Tillage Research 84, 145-153.

Nayak, S., Sunil, B.M., Shrihari, S., (2007). Hydraulic and compaction characteristics of leachate-contaminated lateritic soil. Engineering Geology 94, 137-144

Nielsen, D. \& Kutilek, M., (1995). Soil Hydrology, Catena.

Ozcoban, M.S., Tufekci, N., Tutus, S., Sahib, U. \& Celik, O,. (2006). Leachate removal rate and effect of leachate on the hydraulic conductivity of natural (undisturbed) clay. Journal of Scientific and Industrial Research 65. 264-269

Palmer, B.G., Edil, T.B. \& Benson, C. H., (2000). Liners for waste containment constructed with class F and C fly ashes. Journal of Hazardous Materials 76. 193-216. 
Petrov, R., Rowe, R., (1997). Geosynthetic Clay Liner (GCL) - chemical compatibility by hydraulic conductivity testing and factors impacting its performance. Canadian Geotechnical Journal 34, 863-885.

Radford, B.J., Bridge, B.J., Davis, R.J., McGarry, D., Pillai, U.P., Rickman, J.F., Walsh, P.A. \& Yule, D.F., (2000). Changes in the properties of a vertisol and responses of wheat after compaction with harvester traffic. Soil Till. Res. 54, 155-170.

Rebata-Landa, V., Santamarina, J.C., (2006). Mechanical limits to microbial activity in deep sediments. Geochemistry, Geophysics, Geosystems 7, Q11006.

Roberts, A.A., Shimaoka, T. (2008). Analytical study on the suitability of using bentonite coated gravel as a landfill liner material. Waste Management 28, 2635-2644.

Roehl, K.E., Alamgir, M., Razzaque, M.A., Sarkar, G., (2009). Geoenvironmental properties of clays for landfill construction in Bangladesh. Proceedings of the Internat. Conf. on Solid Waste Manag. Waste Safe 2009, vol 2, pp 503-511, 9-10 Nov. 2009, Khulna, Bangladesh. (Eds. Alamgir et al.). ISBN 978984 33-0761-3.

Schmitz, R.M., (2006). Can the diffuse double layer theory describe changes in hydraulic conductivity of compacted clay? Geotechnical and Geological Engineering 24. 1835-1844

Shan, H.-Y., Lai, Y.-J., (2002). Effect of hydrating liquid on the hydraulic properties of geosynthetic Clay lines. Geotextiles and Geomembranes 20.19-38

Sivapullaiah, P.V., Sridharan, A., Stalin, V.K., (2000). Hydraulic conductivity of bentonitesand mixtures. Canadian Geotechnical Journal 37 (2), 406-413

Tatsi, A.A. \& Zouboulis, A.I., (2002). A field investigation of the quantity and quality of leachate from a municipal solid waste landfill in a Mediterranean climate (Thessaloniki, Greece). Ž. Advances in Environmental Research 6, 207 - 219.

Tigges, U., (2000). Untersuchungen zum mehrdimensionalen Wassertransport unter besonderer Berücksichtigung der Anisotropie der hydraulischen Leitfähigkeit. Ph. D. Thesis. Schriftenreihe des Instituts für Pflanzenernährung und Bodenkunde, Christian Albrechts University, Kiel, Germany, Nr. 56, 145 S. ISBN: 0933-680 X.

Touze-Foltz, N., Duquennoi, C. \& Gaget, C.E., (2006). Hydraulic and mechanical behavior of GCLs in contact with leachate as part of a composite liner. Geotextiles and Geomembranes 24. 188-197

Travar, I., Lidelöwa, S., Andreas L., Thamb, G. \& Lagerkvist, A., (2009). Assessing the environmental impact of ashes used in a landfill cover construction. Waste Management 29.1336-1346.

Vuković, M. \& Soro, A., (1992). Determination of hydraulic conductivity of porous media from grain size distribution. Water Resources Publications, Littleton, Colorado

Wiśniewska, M. \& Stępniewski, W. (2007). The influence of lime, water-glass and clay addition of sealing properties of waste rock from Bogdanka. pp 271-275. In Environmental Engineering (Pawlowski et al. - Eds), Francis and Taylor Group, London, ISBN13 978-0-415-40818-9

Wysocka, A., Stępniewski, W. \& Horn, R., (2007). Swelling-shrinkage properties and hydraulic conductivity of a compacted coal mine tailing rock likely to be used for landfill capping. Int. Agrophysics 21. 405-408

Yavuzcan, H.G, Matthies, D. \& Auernhammer, H., (2005). Vulnerability of Bavarian silty loam to compaction under heavy trafic: impacts of tillage method nad soil water content. Soil \& Tillage Research 84, 200-215 
Zhang, S., Grip, H. \& Lovdahl, L., (2006). Effect of soil compaction on hydraulic properties of two loess soils in China. Soil \& Tillage Research 90, 117-125

Ziyang, L., Youcai, Z., Toa, Y., Yu, S., Huili, C., Nanwen, Z. \& Renhua, H., (2009). Natural attenuation and characterization of contaminants composition in landfill leachate under different disposing ages. Science of the Total Environment 407. 3385-3391. 


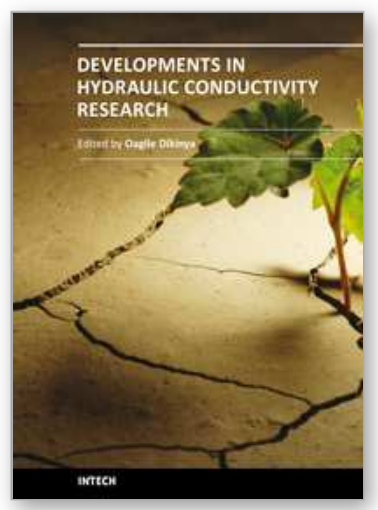

\author{
Developments in Hydraulic Conductivity Research \\ Edited by Dr. Oagile Dikinya
}

ISBN 978-953-307-470-2

Hard cover, 270 pages

Publisher InTech

Published online 28, February, 2011

Published in print edition February, 2011

This book provides the state of the art of the investigation and the in-depth analysis of hydraulic conductivity from the theoretical to semi-empirical models perspective as well as policy development associated with management of land resources emanating from drainage-problem soils. A group of international experts contributed to the development of this book. It is envisaged that this thought provoking book will excite and appeal to academics, engineers, researchers and University students who seek to explore the breadth and indepth knowledge about hydraulic conductivity. Investigation into hydraulic conductivity is important to the understanding of the movement of solutes and water in the terrestrial environment. Transport of these fluids has various implications on the ecology and quality of environment and subsequently sustenance of livelihoods of the increasing world population. In particular, water flow in the vadose zone is of fundamental importance to geoscientists, soil scientists, hydrogeologists and hydrologists and allied professionals.

\title{
How to reference
}

In order to correctly reference this scholarly work, feel free to copy and paste the following:

Witold Stępniewski, Marcin K. Widomski and Rainer Horn (2011). Hydraulic Conductivity and Landfill Construction, Developments in Hydraulic Conductivity Research, Dr. Oagile Dikinya (Ed.), ISBN: 978-953-307470-2, InTech, Available from: http://www.intechopen.com/books/developments-in-hydraulic-conductivityresearch/hydraulic-conductivity-and-landfill-construction

\section{INTECH}

open science | open minds

\section{InTech Europe}

University Campus STeP Ri

Slavka Krautzeka 83/A

51000 Rijeka, Croatia

Phone: +385 (51) 770447

Fax: +385 (51) 686166

www.intechopen.com

\section{InTech China}

Unit 405, Office Block, Hotel Equatorial Shanghai

No.65, Yan An Road (West), Shanghai, 200040, China

中国上海市延安西路65号上海国际贵都大饭店办公楼 405 单元

Phone: +86-21-62489820

Fax: $+86-21-62489821$ 
(C) 2011 The Author(s). Licensee IntechOpen. This chapter is distributed under the terms of the Creative Commons Attribution-NonCommercialShareAlike-3.0 License, which permits use, distribution and reproduction for non-commercial purposes, provided the original is properly cited and derivative works building on this content are distributed under the same license. 